\title{
JALUR PENERIMAAN MAHASISWA BARU BUKAN PENENTU PRESTASI BELAJAR MAHASISWA
}

\author{
Kadek Rai Suwena \\ Jurusan Pendidikan Ekonomi \\ Universitas Pendidikan Ganesha \\ Singaraja, Indonesia \\ e-mail: rai_suwena@undiksha.ac.id
}

\begin{abstract}
Abstrak
Penelitian ini bertujuan untuk mengetahui (1) Prestasi belajar mahasiswa Jurusan Pendidikan Ekonomi yang diterima melalui jalur SNMPTN Undangan, (2) Prestasi belajar mahasiswa Jurusan Pendidikan Ekonomi yang diterima melalui jalur SBMPTN, (3) Prestasi belajar mahasiswa Jurusan Pendidikan Ekonomi yang diterima melalui Jalur Mandiri, dan (4) Perbedaan prestasi belajar mahasiswa Jurusan Pendidikan Ekonomi ditinjau dari jalur penerimaan mahasiswa baru. Penelitian ini adalah penelitian deskriptif komparatif dengan pendekatan kuantitatif. Hasil penelitian menunjukkan bahwa (1) prestasi belajar mahasiswa yang diterima melalui Jalur SNMPTN mengalami peningkatan, (2) prestasi belajar mahasiswa diterima melalui Jalur SBMPTN Tulis mengalami peningkatan, (3) prestasi belajar mahasiswa diterima jalur Mandiri mengalami peningkatan, dan (4) ada perbedaan prestasi belajar mahasiswa Jurusan Pendidikan Ekonomi Undiksha ditinjau dari Jalur Penerimaan SNMPTN Undangan dengan perolehan Mean sebesar 2,8895, Jalur SBMPTN dengan Mean 2,9800, dan Jalur mandiri dengan perolehan Mean 2,8268 dengan tingkat signifikansi $0,001 \%$.
\end{abstract}

Kata kunci: Perbedaan Prestasi Belajar, Jalur Penerimaan Mahasiswa

\begin{abstract}
This study aims to determine (1) The learning achievement of students from the Department of Economic Education received through SNMPTN Invitation, (2) The learning achievement of students from the Department of Economic Education received through SBMPTN, (3) perstasi learning students from the Department of Economic Education received through path Mandiri, and (4) the difference in learning achievement of students from the Department of Economic Education in terms of the path of new admissions. The study was a comparative descriptive study with a quantitative approach. The results showed that (1) the achievement of students accepted through path SNMPTN Invitation increased, (2) the achievement of students accepted through path SBMPTN increased, (3) the achievement of students accepted lane Mandiri increased, and (4) there differences in student achievement Undiksha Economic Education Department in terms of Line SNMPTN Reception Invitation with the acquisition amounted to 2.8895 Mean, Mean Line SBMPTN to 2.9800 , and self Strip with the acquisition of Mean 2.8268 with a significance level of $0.001 \%$.
\end{abstract}

Keywords: Differences in Learning Achievement, track admissions 


\section{PENDAHULUAN}

Kegiatan seleksi masuk perguruan tinggi dimaksudkan untuk memperoleh calon mahasiswa yang unggul. Kesempatan untuk mengikuti seleksi diberikan kepada seluruh siswa/ siswi tamatan SMU/SMK, dan MA. Tes masuk mahasiswa di perguruan tinggi negeri terdiri atas tiga macam jalur seleksi, yaitu Seleksi Nasional Masuk Perguruan Tinggi Negeri (SNMPTN) Jalur Undangan, Seleksi Bersama Masuk Perguruan Tinggi Negeri (SBMPTN), dan Jalur Ujian Mandiri yang diadakan oleh Universitas negeri masing-masing.

Seleksi masuk Perguruan Tinggi Negeri (PTN) Jalur SNMPTN Undangan merupakan jalur seleksi yang pertama diadakan oleh setiap perguruan tinggi negeri di seluruh Indonesia. Seleksi jalur ini mengundang siswa/siswi yang berprestasi disetiap Sekolah Menegah Atas (SMA), Sekolah Menengah Kejuruan (SMK) dan Mandrasah Aliyah (MA) dengan mendaftar melalui sekolah masing - masing. Pada SNMPTN Jalur Undangan sekolah sebagai satuan pendidikan diberikan wewenang melakukan seleksi awal calon mahasiswa yang berprestasi dan selanjutnya dilakukan seleksi dari perguruan tinggi. Akhmad Sudrajat dalam pengantar SNMPTN 2011 menjelaskan bahwa "penerimaan mahasiswa baru melalui SNMPTN Jalur Undangan merupakan kerja sama antara universitas dengan pihak sekolah". Pihak sekolah memberikan data siswa yang berprestasi dan layak diterima menjadi mahasiswa SNMPTN Jalur Undangan. Pendaftaran SNMPTN Undangan dilakukan disekolah asal calon mahasiswa, syarat untuk calon mahasiswa PMDK dibuktikan dengan meningkatnya nilai raport dari semester 1 (satu) sampai dengan semester 5 (lima).

Siswa/siswi tamatan SMU/SMK, dan MA yang ingin melanjutkan ke PTN dapat juga mengikuti jalur yang kedua yaitu SBMPTN. SBMPTN atau dulunya disebut dengan Seleksi Penerimaan Mahasiswa Baru (SPMB) merupakan seleksi mahasiswa yang diadakan secara serentak oleh beberapa perguruan tinggi negeri di seluruh Indonesia dan dikoordinir oleh panitia lokal setiap regional. Mahasiswa yang masuk ke perguruan tinggi negeri melalui SBMPTN telah menyisihkan calon-calon mahasiswa yang akan kuliah di perguran tinggi negeri seluruh Indonesia. Kegiatan penseleksian pada SBMPTN dilakukan dengan melalui serangkaian tes, diantaranya Tes Potensi Akademik (TPA), Tes Bidang Studi Dasar (TBSD), tes bidang studi dan tes keterampilan. Pada SBMPTN, calon mahasiswa dapat dikatakan lulus seleksi apabila memenuhi passing grade yang telah ditentukan dari pihak universitas. Pada jalur ini mahasiswa yang diterima dituntut mampu bersaing dengan mahasiswa lain yang diterima di perguruan tinggi tanpa melalui tes. Mahasiswa yang masuk melalui jalur ini berbeda dengan mahasiswa yang diterima melalui jalur SBMPTN Undangan. Mahasiswa yang masuk melalui jalur undangan merupakan mahasiswa yang diistimewakan, karena diterima tanpa melalui tes.

Jalur penerimaan mahasiswa yang paling terakhir dilakukan pada masing masing perguruan tinggi adalah Jalur Mandiri. Ujian mandiri yang diadakan oleh universitas negeri seluruh Indonesia diadakan oleh universitas masing-masing, jalur ini sama seperti jalur SBMPTN, dimana sebelum diterima di Perguruan Tinggi Negeri (PTN) harus melakukan tes sedemikian rupa sama seperti tes yang dilakukan pada SBMPTN. Mahasiswa yang diterima dari Jalur Mandiri dalam menempuh perkuliahan dikenakan biaya yang lebih tinggi dibandingkan dengan biaya kuliah mahasiswa yang masuk melalui jalur SBMPTN. Dasar Hukum Untuk Penerimaan Mahasiswa S-1 pada perguruan tinggi yang dikelola oleh pemerintah, sistem penerimaan diatur oleh PP No 66 Tahun 2010. Karena dilaksanakan secara mandiri oleh masingmasing perguruan tinggi negeri (tidak seperti SBMPTN yang dilaksanakan secara bersama-sama di bawah koordinasi Direktur Jendral Pendidikan 
Tinggi, Kementerian Pendidikan Nasional), Jalur Mandiri dilaksanakan secara tidak seragam dan bergantung kepada kebijakan masing-masing perguruan tinggi negeri.

Mahasiswa yang lolos melalui salah satu jalur penerimaan masuk PTN dibagi menjadi beberapa kelas yang berbeda sesuai dengan jalur yang telah mereka tempuh. Mahasiswa dikatakan berhasil atau tidak dalam proses perkuliahan caranya dengan melihat nilai-nilai hasil perolehan mahasiswa dalam Kartu Hasil Studi (KHS) yang mencerminkan prestasi belajar atau sejauh mana tingkat keberhasilan mahasiswa mengikuti kegiatan belajar. Menurut Sugihartono (2007: 130) dalam kegiatan belajar mengajar, "pengukuran hasil belajar dimaksudkan untuk mengetahui seberapa jauh perubahan tingkah laku mahasiswa setelah menghayati proses belajar, maka pengukuran yang dilakukan dosen lazimnya menggunakan tes sebagai alat ukur". Hasil pengukuran tersebut berwujud angka ataupun pernyataan yang mencerminkan tingkat penguasaan materi pelajaran bagi para mahasiswa, yang lebih dikenal dengan prestasi belajar

Tinggi rendahnya prestasi belajar mencerminkan kualitas pendidikan. Kualitas pendidikan yang baik dapat dicapai dengan cara menerapkan proses belajar mengajar yang efektif dan efisien. Prestasi belajar dapat dikelompokkan menjadi prestasi belajar seluruh bidang studi dan prestasi belajar bidang tertentu. Prestasi belajar merupakan bagian akhir dari proses belajar, calon mahasiswa dapat menyelesaikan studi dengan cepat yakni menurut Buku Pedoman Akademik Undiksha (2011) disebutkan bahwa jumlah sks program S1 berkisar 146 sks atau sama dengan 8 semester.

Dalam kegiatan pembelajaran, mahasiswa dikatakan berhasil atau tidak, salah satu caranya dengan melihat nilai nilai hasil perolehan mahasiswa dalam Kartu Hasil Studi (KHS) yang mencerminkan prestasi belajar atau sejauh mana tingkat keberhasilan siswa mengikuti kegiatan belajar. Diawal perkuliahan biasanya dosen menetapkan aturan selama kuliah berlangsung yang disepakati keduanya pada semester tersebut. Aturan tersebut sebagai berikut. (1) Kehadiran : Kehadiran mahasiswa tiap jam perkuliahan dan keaktifan mahasiswa selama jam perkuliahan; (2) Tugas: Dosen selalu memberikan tugas kepada mahasiswa. Tugas yang diberikandapat berupa tugas kelompok atau individu; (3) Nilai Ujian Tengah Semester: Ujian ini dilaksanakan tiap tengah semester.Beberapa dosenada yang memberikan soal ujian tengah semester ada juga yang tidak; (4) Nilai Ujian Akhir Semester: Nilai ini akan diperoleh mahasiswa pada akhir semester dengan mengikuti ujian yang dilaksanakan oleh dosen masing-masing.

Berdasarkan Buku Pedoman Studi Universitas Pendidikan Ganesha predikat kelulusan program $\mathrm{S} 1$ ada tiga yaitu sebagai berikut. (1) $3,51-4,00=$ predikatnya: lulus dengan pujian (cumlaude); (2) $2,75-3,50$ = predikatnya: sangat memuaskan; (3) $2,00-2,75=$ predikatnya: memuaskan

Universitas Pendidikan Ganesha (Undiksha) merupakan salah satu PTN yang menjadi tujuan siswa setelah meninggalkan bangku SMA. Proses penerimaan mahasiswa baru di Undiksha menggunakan tiga jalur yakni, SNMPTN Undangan, SBMPTN, dan Jalur Mandiri. Kegiatan penyeleksian untuk memperoleh calon mahasiswa unggul dengan memberi kesempatan kepada masyarakat secara lebih luas untuk menjadi mahasiswa dan berkontribusi dalam meningkatkan kualitas pendidikan di Undiksha. Jurusan Pendidikan Ekonomi merupakan salah satu jurusan yang berada di bawah naungan Undiksha. Mahasiswa Jurusan Pendidikan Ekonomi diterima melalui ketiga jalur penyeleksian masuk perguruan tinggi negeri.

Berdasarkan hasil seleksi dari ketiga jalur penerimaan mahasiswa di Jurusan Pendidikan Ekonomi, diperoleh data ratarata IPK mahasiswa dari narasumber langsung yaitu mahasiswa Jurusan Pendidikan Ekonomi tahun angkatan 
2011. Keseluruhan mahasiswa yang diterima melalui ketiga jalur seleksi masuk perguruan tinggi negeri pada tahun angkatan 2011 berjumlah 57 orang, dengan masing - masing jalur memiliki proporsi mahasiswa yang tidak sama. Jalur SNMPTN Undangan jumlah mahasiswanya 19 orang dengan rata-rata IPK 2.89, jalur SBMPTN jumlah mahasiswanya 19 orang dengan rata-rata IPK 2.98, dan mahasiswa yang diterima melalui Jalur Mandiri berjumlah 19 orang dengan rata - rata IPK sebesar 2.83. Dari data yang diperopeh dilapangan tersebut terjadi penyimpangan antara prestasi belajar mahasiswa dengan jalur penerimaan mahasiswa baru. Mahasiswa yang masuk melalui jalur SNMPTN merupakan siswa yang memiliki prestasi akademik yang tinggi hal tersebut sudah diatur dalam Peraturan Pemerintah Republik Indonesia Nomor 66 Tahun 2010 tentang penerimaan mahasiswa nasional, sehingga mampu bersaing dengan siswasiswa dari sekolah lain. Mahasiswa yang masuk melalui jalur SNMPTN Undangan ini adalah mahasiswa yang diistimewakan karena diterima di PTN tanpa melakukan tes. Siswa dinyatakan diterima apabila nilai rapornya memenuhi syarat yang telah ditentukan. Namun pada kenyataannya, mahasiswa yang masuk melalui jalur penerimaan mahasiswa baru SNMPTN Undangan prestasi belajarnya masih rendah dibandingkan dengan mahasiswa yang diterima melalui jalur SBMPTN. Dengan berbagai kemudahan yang diterima oleh mahasiswa yang masuk melalui jalur SNMPTN Undangan, hal tersebut belum mampu untuk memberikan kontribusi dalam meningkatkan prestasi belajar mahasiswa di Perguruan Tinggi Negeri, dari permasalahan dilapangan tersebut menjadi landasan peneliti untuk mengetahui perbedaan "Studi Komparatif Prestasi Belajar Mahasiswa Jurusan Pendidikan Ekonomi Undiksha Ditinjau Dari Jalur Penerimaan Mahasiswa Baru".

\section{METODE}

Penelitian ini dilakukan di Undiksha dengan fokus pengamatan penerimaan mahasiswa baru jalur SNMPTN Undangan, SBMPTN, dan jalur Mandiri di Jurusan Pendidikan Ekonomi, Fakultas Ekonomi, oleh karena itu penelitian ini menggunakan rancangan deskriptif komparatif, yaitu penelitian yang menggambarkan atau menerangkan gejala dari variabel-variabel yang digunakan untuk mengetahui perbedaan. Tahap-tahap dalam penelitian diawali dengan merumuskan masalah, mencari teori, menemukan jawaban teoritis, pengumpulan data, mengelola data, dan menarik kesimpulan. Menurut Nazir (2005: 58) "penelitian komparatif adalah sejenis penelitian deskriptif yang ingin mencari jawaban secara mendasar tentang sebab akibat, dengan menganalisis faktor-faktor penyebab terjadinya ataupun munculnya suatu fenomena tertentu". Menguji hipotesis komparatif berarti menguji parameter populasi yang berbentuk perbandingan melalui ukuran sampel yang juga berbentuk perbandingan.

Adapun yang menjadi subjek penelitian adalah mahasiswa Jurusan Pendidikan Ekonomi, Fakultas Ekonomi Undiksha, yang diterima melalui penerimaan SNMPTN jalur Undangan, SBMPTN, dan jalur Mandiri. Objek penelitiannya adalah prestasi belajar mahasiswa ditinjau dari IPK. Sumber data dari penelitian ini adalah data kuantitatif dan data kualitatif. Metode pengumpulan data yang digunakan adalah metode dokumentasi dan wawancara. Analisis data yang digunakan adalah Analisis Trend, dan Anava Satu Arah (one way of anova).

\section{HASIL DAN PEMBAHASAN}

\section{HASIL}

Prestasi Belajar Mahasiswa Yang Diterima Melalui Jalur SNMPTN Undangan

Berdasarkan hasil penelitian yang telah dilakukan, prestasi belajar mahasiswa yang diterima melalui Jalur SNMPTN Undangan Jurusan Pendidikan Ekonomi Universitas Pendidikan Ganesha angkatan tahun 2011 dari 19 responden, dapat diketahui 15 orang mahasiswa 
(78,95\%) pada semester II prestasi belajarnya mengalami peningkatan dan 4 mahasiswa $(21,05 \%) \quad$ mengalami penurunan. Pada semester III, 2 orang mahasiswa $(10,5 \%)$ prestasi belajarnya mengalami peningkatan dan 16 orang mahasiswa $(84,21 \%) \quad$ cenderung mengalami penurunan. Pada semester IV, 15 orang mahasiswa $(78,95 \%)$ prestasi belajarnya cenderung meningkat dan 4 orang mahasiswa $(21,05 \%)$ mengalami penurunan, pada semester $\mathrm{V}, 14$ orang mahasiswa $(73,68 \%)$ prestasi belajarnya cenderung meningkat dan 5 orang mahasiswa (26,32\%) mengalami penurunan, pada semester, $\mathrm{VI}, 16$ orang mahasiswa $(84,21 \%)$ prestasi belajarnya cenderung meningkat dan 3 orang mahasiswa $(15,79 \%) \quad$ mengalami penurunan, pada semester VII, 6 orang mahasiswa $(31,58 \%)$ prestasi belajarnya mengalami peningkatan dan 12 orang mahasiswa $(63,16 \%) \quad$ cenderung mengalami penurunan dan semester VIII, 4 orang mahasiswa $(21,05 \%)$ prestasi belajarnya mengalami peningkatan dan 15 orang mahasiswa $(78,95 \%)$ cenderung mengalami penurunan. Pada jalur ini peningkatan yang signifikan terjadi pada semester VI yaitu dengan jumlah 16 orang mahasiswa $(84,21 \%)$, dan penurunan yang drastis terjadi pada semester III dengan jumlah 16 orang mahasiswa $(84,21 \%)$.

Prestasi Belajar Mahasiswa Yang Diterima Melalui Jalur SBMPTN

Berdasarkan hasil penelitian yang telah dilakukan, prestasi belajar mahasiswa yang diterima melaui Jalur SBMPTN Tulis Jurusan Pendidikan Ekonomi Universitas Pendidikan Ganesha angkatan tahun 2011 dari 19 responden, dapat disimpulkan bahwa prestasi belajar mahasiswa pada semester II terdapat 17 orang mahasiswa $(89,47 \%)$ prestasi belajarnya mengalami peningkatan dan 2 orang mahasiswa (10,53\%) mengalami penurunan, pada semester III, 3 orang mahasiswa (15,79\%) prestasi belajarnya mengalami peningkatan dan 15 orang mahasiswa $\quad(78,95 \%) \quad$ cenderung mengalami penurunan, pada semester IV, 15 orang mahasiswa (78,95\%) prestasi belajarnya cenderung meningkat dan 4 orang mahasiswa $(21,05 \%)$ mengalami penurunan, pada semester $\mathrm{V}, 7$ orang mahasiswa $(36,84 \%)$ prestasi belajarnya mengalami peningkatan dan 12 orang mahasiswa $\quad(64,16 \%) \quad$ cenderung mengalami penurunan, pada semester VI, 14 orang mahasiswa $(73,68 \%)$ prestasi belajarnya cenderung meningkat dan 5 orang mahasiswa $(26,32 \%)$ mengalami penurunan, pada semester VII, 12 orang mahasiswa $(63,16 \%)$ prestasi belajarnya cenderung meningkat dan 7 orang mahasiswa (36,84\%) mengalami penurunan dan semester VIII, 6 orang mahasiswa $(31,58 \%)$ prestasi belajarnya mengalami peningkatan dan 13 orang mahasiswa $\quad(68,42 \%) \quad$ cenderung mengalami penurunan. Pada jalur ini peningkatan yang signifikan terjadi pada semester II yaitu dengan jumlah 17 orang mahasiswa $(89,47 \%)$, dan penurunan yang drastis terjadi pada semester III dengan jumlah 15 orang mahasiswa (78,95\%).

\section{Prestasi Belajar Mahasiswa Yang Diterima Melalui Jalur Mandiri \\ Berdasarkan hasil penelitian yang} telah dilakukan, prestasi belajar mahasiswa yang diterima melaui Jalur Mandiri Jurusan Pendidikan Ekonomi Universitas Pendidikan Ganesha angkatan tahun 2011 dari 19 responden, dapat diketahui bahwa prestasi belajar pada semester II, 17 orang mahasiswa $(84,21 \%)$ prestasi belajarnya mengalami peningkatan dan 3 orang mahasiswa $(15,79 \%)$ mengalami penurunan, pada semester III, 2 orang mahasiswa (10,5\%) prestasi belajarnya mengalami peningkatan dan 17 orang mahasiswa $(89,5 \%) \quad$ cenderung mengalami penurunan, pada semester IV, 13 orang mahasiswa $(68,42 \%)$ prestasi belajarnya cenderung meningkat dan 6 orang mahasiswa $(31,58 \%) \quad$ mengalami penurunan, pada semester $\mathrm{V}, 6$ orang mahasiswa $(31,58 \%)$ prestasi belajarnya mengalami peningkatan dan 12 orang 
mahasiswa $\quad(63,16 \%) \quad$ cenderung mengalami penurunan, pada semester $\mathrm{VI}$, 13 orang mahasiswa $(68,42 \%)$ prestasi belajarnya cenderung mengalami peningkatan dan 5 orang mahasiswa $(26,34 \%)$ mengalami penurunan, pada semester VII, 14 orang mahasiswa $(73,68 \%)$ prestasi belajarnya cenderung mengalami peningkatan dan 4 orang mahasiswa $(21,05 \%) \quad$ mengalami penurunandan semester VIII, 3 orang mahasisawa $(15,79 \%)$ prestasinya mengalami peningkatan dan 16 mahasiswa $\quad(84,21 \%) \quad$ cenderung mengalami penurunan. Pada jalur ini peningkatan yang signifikan terjadi pada semester II yaitu dengan jumlah 16 orang mahasiswa $(84,21 \%)$, dan penurunan yang drastis terjadi pada semester VIII dengan jumlah 16 orang mahasiswa $(84,21 \%)$.

Perbandingan Prestasi Belajar Mahasiswa Yang Diterima Melalui Jalur Penerimaan Mahasiswa SNMPTN Undangan, SBMPTN, Jalur Mandiri

Ada perbedaan antara prestasi belajar mahasiswa ditinjau dari jalur penerimaan yaitu SNMPTN Undangan, SBMPTN, dan Jalur Mandiri. Berdasarkan rata-rata prestasi belajar mahasiswa yang diterima Jalur SNMPTN diperoleh mean 2.8895 , prestasi belajar mahasiswa yang diterima Jalur SBMPTN diperoleh mean 2.9800, dan prestasi belajar mahasiswa yang diterima Jalur Mandiri diperoleh mean 2.8268. Dengan demikian, dari nilai rata-rata yang diperoleh tersebut dapat ditarik keseimpulan bahwa ada perbedaan tentang prestasi belajar antara mahasiswa yang diterima melalui Jalur SNMPTN Undangan, SBMPTN, dan Jalur Mandiri di Jurusan Pendidikan Ekonomi angkatan tahun 2011 Fakultas Ekonomi Universitas Pendidikan Ganesha.

\section{PEMBAHASAN}

Prestasi belajar adalah hasil penilaian dari kegiatan belajar yang telah dilakukan dan merupakan bentuk perumusan akhir yang diberikan oleh dosen untuk melihat sampai di mana kemampuan mahasiswa yang dinyatakan dalam bentuk simbol, angka, huruf maupun kalimat yang dapat mencerminkan hasil yanmg sudah dicapai. Penilaian adalah kegiatan yang dilakukan oleh pelatih yaitu pendidik (guru dan dosen) untuk mengukur dan mengetahui tingkat keberhasilan proses dan hasil belajar mengajar dalam perkuliahan. Penilaian proses adalah penilaian yang dilakukan pada saat kegiatan belajar mengajar berlangsung, sedangkan penilaian akhir dari proses belajar mengajar tertera pada Kartu Hasil Studi (KHS). Prestasi belajar adalah kemampuan individu dalam proses belajar dapat dilihat dari Indeks Prestasi (IP). Perolehan prestasi belajar mahasiswa dilihat dari indeks prestasi tidak terlepas dari kualitas mahasiswa saat dilakukan tahap seleksi mahasiswa baru. Dilakukannya seleksi mahasiswa baru bertujuan agar calon mahasiswa yang akan masuk ke perguruan tinggi memiliki kualitas yang baik. Oleh sebab itu, setiap perguruan tinggi terutama perguruan tinggi negeri selalu melakukan beberapa tahap seleksi mahasiswa baru. Universitas Pendidikan Ganesha (Undiksha) merupakan salah satu PTN yang menjadi tujuan siswa setelah meninggalkan bangku SMA/SMK, dan MA. Proses penerimaan mahasiswa baru di Undiksha menggunakan tiga jalur yakni, SNMPTN Undangan, SBMPTN, dan Jalur Mandiri. Kegiatan penyeleksian untuk memperoleh calon mahasiswa unggul dengan memberi kesempatan kepada masyarakat secara lebih luas untuk menjadi mahasiswa dan berkontribusi dalam meningkatkan kualitas pendidikan di Undiksha. Dari ketiga tahap seleksi ini, SNMPTN Undangan yang diharapkan memiliki kualitas yang paling unggul. Harapan tersebut muncul karena dalam tahap penerimaan mahasiswa baru dengan SNMPTN Undangan merupakan siswa yang lolos pada seleksi nasional berdasarkan hasil penelusuran prestasi akademik dengan menggunakan nilai rapor semester 1 (satu) sampai dengan semester 5 (lima) bagi SMA/MA dan SMK/MAK yang masa belajarnya 3 (tiga)

Kadek Rai Suwena | 6 dari 69 
tahun dan portofolio akademik. Pada kenyataannya hal ini tidak sesuai dengan hasil penelitian ini, yang dimana dapat dilihat bahwa rata-rata prestasi belajar mahasiswa yang lolos melalui tahap SNMPTN Undangan lebih rendah dibandingkan dengan mahasiswa yang diterima melalui tahap SBMPTN.

Perbedaan prestasi belajar antara mahasiswa yang masuk jalur SNMPTN Undangan, SBMPTN, dan Jalur Mandiri juga terlihat jelas dalam hasil penelitian. Berdasarkan rata-rata prestasi belajar mahasiswa yang diterima Jalur SNMPTN Undangan diperoleh mean 2.8895, prestasi belajar mahasiswa yang diterima Jalur SBMPTN diperoleh mean 2.9800, dan prestasi belajar mahasiswa yang diterima Jalur Mandiri diperoleh mean 2.8268, dapat diketahui bahwa terdapat perbedaan antara prestasi belajar mahasiwa antara mahasiswa yang masuk melalui masuk jalur SNMPTN Undangan, SBMPTN, dan Jalur Mandiri. Hasil penelitian ini tidak sejalan dengan tujuan dari seleksi SNMPTN undangan. Mahasiswa yang diterima melalui jalur ini juga sangat diistimewakan dengan diterima tanpa tes. Berbeda dengan mahasiswa yang masuk melalui SBMPTN, sebelum diterima terlebih dahulu melakukan tes yang diantaranya Tes Potensi Akademik (TPA), dan Tes Bidang Studi Dasar (TBDS). Sedangkan mahasiswa yang diterima melalui Jalur Mandiri hampir sama dengan mahasiswa yang diterima melalui Jalur SBMPTN, hanya saja biaya kuliah per semesternya lebih tinggi.

Dari hasil penelitian yang telah dilakukan perlu dikaji kembali mengenai ketiga jalur penerimaan mahasiswa baru, kemungkinan ada faktor-faktor yang mempengaruhi prestasinya berbada ketika di bangku SMA, SMK, MA dengan preastasinya dibangku kuliah, atau standar penilaian masing-masing sekolah yang berbeda mengingat kebanyakan nilai yang di berikan di sekolah terkadang tidak sesuai dengan kemampuannya. Menurut Sugihartono (2007: 74) "belajar merupakan suatu proses memperoleh pengetahuan dan pengalaman dalam wujud perubahan tingkah laku dan kemampuan bereaksi yang relatif permanen atau menetap karena adanya interaksi individu dengan lingkungannya". Sejalan dengan yang dikatakan Slameto (2010: 2) bahwa "belajar ialah suatu proses usaha yang dilakukan seseorang untuk memperoleh suatu perubahan tingkah laku yang baru secara keseluruhan, sebagai hasil pengalamannya sendiri dalam interaksi dengan lingkungannya".

Faktor lingkungan berpengaruh besar terhadap prestasi belajar mahasiswa. Faktor lingkungan yang dimaksud adalah faktor yang berasal dari luar mahasiswa atau faktor eksternal. Lingkungan sekitar baik teman, tetangga, teman sepermainan dan yang paling penting keluarga mahasiswa khususnya orang tua yang dapat membantu mahasiswa dalam proses belajar. Lingkungan sosial yang banyak mempengaruhi kegiatan belajar adalah orang tua dan keluarga mahasiswa itu sendiri. Keluarga merupakan tempat dimana anak melakukan sosialisasi untuk yang pertama kalinya dan lingkungan pertama dalam pembentukan kepribadian kemampuan anak. Pentingnya pendidikan anak di lingkungan keluarga menjadikan keluarga mempunyai pengaruh yang kuat terhadap keberhasilan anak. Cara orang tua mendidik, suasana rumah, keadaan ekonomi keluarga, pengertian orang tua dan latar kebudayaan juga akan berpengaruh terhadap prestasi belajar anak. Faktor lingkungan juga sangat berpengaruh terhadap segala sesuatu yang menjadi sebuah pilihan bagi anak. Hal ini diketahui dari setelah anak lulus SMA, SMK, dan MA yang ingin melanjutkan studinya terkadang lebih sering memperoleh informasi penerimaan mahasiswa sebuah perguruan tinggi dari orang-orang terdekat di sekitarnya. Sehingga mereka menentukan pilihan jurusan terkadang tidak sesuai dengan kemampuannya.

Dari hasil observasi yang dilakukan
juga ditemukan bahwa prestasi

Kadek Rai Suwena | 7 dari 69 
mahasiswa rendah karena mereka tidak bisa menyesuaikan diri dengan lingkungannya. Dengan lingkungan yang sedikit berbeda pada saat mereka duduk di bangku sekolah. Pada saat mereka duduk di bangku sekolah yang selalu dibawah pengawasan orang tua namun pada saat menempuh pendidikan di perguruan tinggi jauh dari pengawasan orang tua dengan lingkungan yang berbeda serta kurangnya kontrol dari orang tua menyebabkan pretasi belajar mereka rendah. Jadi faktor yang utama menentukan prestasi belajar mahasiswa tersebut adalah faktor lingkungan, bukan dilihat dari jalur mereka masuk perguruan tinggi.

\section{SIMPULAN}

Berdasarkan hasil penelitian yang dilakukan, maka dapat ditarik simpulan sebagai berikut. (1) Prestasi belajar mahasiswa yang diterima melaui Jalur SNMPTN Undangan Jurusan Pendidikan Ekonomi Universitas Pendidikan Ganesha angkatan tahun 2011 memiliki rata-rata IP 2,89. Dari rata-rata nilai IP mahasiswa yang diterima melalui Jalur SNMPTN Undangan tergolong dalam kategori baik karena nilai 2,89 berada pada rentangan 2,50 - 3,25; (2) Prestasi belajar mahasiswa yang diterima melaui Jalur SBMPTN Jurusan Pendidikan Ekonomi Universitas Pendidikan Ganesha angkatan tahun 2011 memiliki rata-rata IP 2,98. Dari rata-rata nilai IP mahasiswa yang diterima melalui Jalur SNMPTN Tuli, tergolong dalam kategori baik karena nilai 2,98 berada pada rentangan 2,50 - 3,25; (3) Prestasi belajar mahasiswa yang diterima melaui Jalur Mandiri Jurusan Pendidikan Ekonomi Universitas Pendidikan Ganesha angkatan tahun 2011 memiliki rata-rata IP 2,83. Dari rata-rata nilai IP mahasiswa yang diterima melalui Jalur Mandiri tergolong dalam kategori baik karena nilai 2,83 berada pada rentangan $2,50-3,25$; (4) Ada perbedaan antara prestasi belajar mahasiswa ditinjau dari jalur penerimaan yaitu SNMPTN Undangan, SBMPTN, dan Jalur Mandiri. Berdasarkan rata-rata prestasi belajar mahasiswa yang diterima
Jalur Undangan diperoleh mean 2.8895, prestasi belajar mahasiswa yang diterima Jalur SBMPTN diperoleh mean 2.9800, dan prestasi belajar mahasiswa yang diterima Jalur Mandiri diperoleh mean 2.8268. Dengan demikian, dari nilai ratarata yang diperoleh tersebut dapat ditarik keseimpulan bahwa ada perbedaan tentang prestasi belajar antara mahasiswa yang diterima melalui Jalur Undangan, Jalur SBMPTN, dan Jalur Mandiri di Jurusan Pendidikan Ekonomi angkatan tahun 2011 Fakultas Ekonomi Universitas Pendidikan Ganesha.

\section{SARAN}

Berdasarkan penelitian yang telah dilakukan, adapun saran yang dapat diberikan peneliti adalah sebagai berikut. (1) Perlu dikaji kembali mengenai proses penerimaan mahasiswa baru, bahwa tidak selalu prestasi belajar mahasiswa yang diterima melalui jalur SNMPTN Undangan pada masa perkuliahan sejalan dengan apa yang diharapkan atau dengan kata lain mahasiswa yang diterima melalui jalur SBMPTN Tulis dan Jalur Mandiri prestasi belajarnya lebih rendah dibandingkan dengan mahasiswa yang diterima melalui jalur SNMPTN Undangan; (2) Perlu disadari bahwa prestasi belajar mahasiswa dalam mengikuti perkuliahan tidak ditentukan dari jalur penerimaannya. Ada faktor lain yang lebih berpengaruh terhadap prestasi belajar mahasiswa, yaitu faktor lingkungan. Baik lingkungan keluarga ataupun lingkungan sekitar dimana mahasiswa tersebut beradaptasi.

\section{DAFTAR PUSTAKA}

Pedoman Studi Universitas Pendidikan GaneshaTahun 2011. Singaraja : Undiksha Universitas Pendidikan Ganesha. 2011

Pengertian Penerimaan Mahasiswa Jalur SNMPTN Undangandan Peserta Tahun $2011 \quad$ Tersedia pada:http://id.wikipedia.org/wiki/Sele ksi_Nasional_Masuk_Perguruan_Tin ggi_Negeri\#Jalur_Undangan (diakses 20 Januari 2015)

Kadek Rai Suwena | 8 dari 69 

Pengertian Penerimaan Mahasiswa Jalur SNMPTN Undangan dan Peserta Tahun $2011 \quad$ Tersedia pada:http://id.wikipedia.org/wiki/Sele ksi_Nasional_Masuk_Perguruan_Tin ggi_Negeri,http://id.wikipedia.org/wik i/Seleksi_Nasional_Masuk_Pergurua n_Tinggi_Negeri\#Jalur_Ujian_Tertuli s_2 (diakses 20 Januari 2015)

Peraturan Pemerintah Nomor 17 Tahun 2010 tentang Pengelolaan dan Penyelenggaraan Pendidikan, Peraturan Menteri Pendidikan Nasional Nomor 34 Tahun 2010 tentang Pola Penerimaan Mahasiswa Baru Program Sarjana pada Perguruan Tinggi Tersedia pada http://www.snmptn.ac.id/informasi.ht ml?1392625573Full.pdf (diaskes pada 14 Januari 2015)

Peraturan Pemerintah Nomor 66 tahun 2010 atas Perubahan Peraturan Pemerintah Nomor 17 Tahun 2010 tentang Pengelolaan dan Penyelenggaraan Pendidikan, Peraturan Menteri Pendidikan Nasional Tersedia pada : http://aturan.dikti.go.id/upload/penjelpp66.pdf (diakses pada 3 Maret 2015)

Slameto. 2010. Belajar dan Faktor-faktor yang Mempengaruhinya. Jakarta: PT Rineka Cipta

Sugihartono, dkk. 2007. Psikologi Pendidikan. Yogyakarta: UNY Press

Sugiyono. 2009. Metode Penelitian Kuantitatif Kualitatif dan $R \& D$. Bandung: Álfabeta

---------, 2010. Metode Penelitian Kuantitatif Kualitatif dan R\&D. Bandung: Álfabeta

Sugiyono. 2010. Metode Penelitian Bisnis. Bandung: Alfabeta 
